\title{
Spatial Distribution of Toxic Sites in Louisiana, USA: The GIS Perspectives
}

\author{
Yaw A. Twumasi1*, Edmund C. Merem², John B. Namwamba1, \\ Sabrina A. Welch ${ }^{3}$, Tomas Ayala-Silva ${ }^{4}$, Ronald Okwemba ${ }^{1}$, \\ Kamran Abdollahi'1, Onyumbe E. Ben Lukongo5, \\ Kellyn LaCour-Conant ${ }^{1}$, Joshua Tate ${ }^{1}$, Caroline 0. Akinrinwoye ${ }^{1}$
}

\footnotetext{
${ }^{1}$ Department of Urban Forestry and Natural Resources, Southern University and A \& M College, Fisher Hall, Baton Rouge, Louisiana, USA

${ }^{2}$ Department of Urban and Regional Planning, Jackson State University, Capitol Center, Jackson, Mississippi, USA

${ }^{3}$ Department of Civil Engineering, Jackson State University, Jackson, MS, USA

${ }^{4}$ USDA-ARS Tropical Agriculture Research Station, Mayaguez, Puerto Rico, USA

${ }^{5}$ Department of Public Policy, Southern University and A \& M College, Nelson Mandela College of Government and Social Sciences, Baton Rouge, Louisiana, USA

Email: ^yaw.twumasi@subr.edu, *yaw.twumasi@gmail.com
}

How to cite this paper: Twumasi, Y.A., Merem, E.C., Namwamba, J.B., Welch, S.A., Ayala-Silva, T., Okwemba, R., Abdollahi, K., Lukongo, O.E.B., LaCour-Conant, K., Tate, J. and Akinrinwoye, C.O. (2020) Spatial Distribution of Toxic Sites in Louisiana, USA: The GIS Perspectives. International Journal of Geosciences, 11, 288-303. https://doi.org/10.4236/ijg.2020.114015

Received: February 27, 2020

Accepted: April 24, 2020

Published: April 27, 2020

Copyright (C) 2020 by author(s) and Scientific Research Publishing Inc. This work is licensed under the Creative Commons Attribution International License (CC BY 4.0).

http://creativecommons.org/licenses/by/4.0/ (c) (i) Open Access

\begin{abstract}
This study uses geographic Information System (GIS) techniques to spatially geocode the affected toxic site areas in Louisiana and use the results to help policy-makers plan for removal. Data for this study was acquired from the United States Environmental Protection Agency (EPA) website including names and locations of National Priorities List (NPL). Also, publicly available EPA database that contains information on toxic chemical releases and other waste management activities reported annually by regulated industry groups and federal facilities was acquired. Data obtained from EPA website was converted to geographic co-ordinates (latitude and longitude). Results showed geocoded toxic wastes maps in Louisiana. Results also revealed that most of the toxic sites were clustered around major waterways in both southern and northern Louisiana. Policy recommendations include strict enforcement of the State laws that deal with fracking and flaring, use of emission inventories and air quality reports to assist policy makers in developing cost-effective emission control strategies that are necessary for tracking the progress of policies towards gas emissions reduction and finally, the need to increase funding for the clean-up of the chemical waste.
\end{abstract}

\section{Keywords}

GIS, Toxic Waste, Superfund, Louisiana 


\section{Introduction}

Hazardous waste sites pollution is a global problem. It is estimated that more than 500,000 humans have died and 10 million have suffered from chemical spills. In the last 40 years, about 200 million people have been at risk of exposure to toxic and hazardous waste sites pollution poisoning globally [1]. It is also observed that chemical spills contamination has taken the dimension of epidemiological problems in the United States [2] [3]. Chemical spills and hazardous waste sites are some of the major issues confronting both states and federal governments because of accompanying health-related issues [4]. Hazardous waste contamination poses a significant threat to the environment. In 1980, legislation was passed by congress to create the Superfund program at United States Environmental Protection Agency (EPA) to identify and clean up harsh hazardous waste sites to jump start and fund cleanup efforts [4]. Since then billions of dollars have been spent cleaning up Superfund sites. Toxic waste disasters are almost always associated with the industrial use of, or management of, harmful chemicals and or their by-products. Unlined or poorly lined landfill pits, leaky storage tanks and the irresponsible disposal of industrial waste are common causes which ensue hazardous waste disasters. These harmful contaminants seep into the soil from industrial sites and subsequently pollute the soil and any existing downstream water supply. The toxins render the soil unsuitable for agricultural use and the water non-potable and unsafe for domestic use, moreover, some of these toxins are known carcinogens. The EPA, through The Comprehensive Environmental Response, Compensation, and Liability Act of 1980 (CERCLA), also known as Superfund, endeavors to combat these environmental threats by identifying hazardous waste sites across the US where clean-up efforts will be employed. Polluted sites are added to the EPA's National Priorities List (NPL) for cleanup and remediation of the nation's uncontrolled and environmentally contaminated sites and ranked as either a long-term or short-term project (Figure 1). Upon completion of remedial actions, the sites are removed from the NPL list and prepared for reuse when possible. Most of these Superfund sites are clearly marked or identified with EPA sign board to show the existence of hazardous waste (Figure 2).

Besides health issues, dumping of hazardous waste poses a significant threat to the environment. The Environmental Protection Agency's (EPA) 1995 data shows that EPA managed about 277 million metric tons of hazardous waste at licensed Resource Conservation and Recovery Act (RCRA) sites. EPA also estimated that U.S. factories released 1.8 million metric tons (about 2 million tons) of toxic chemicals into the air, land, and surface waters in 2011, including a number of chemicals that are known carcinogens.

Each year millions of dollars are spent by both states and federal governments to clean up contaminated sites. Notwithstanding the gravity of the issue, very little has been done to track the problems with Geographic Information Systems (GIS) in Louisiana. However, GIS has found widespread appeal in mapping and 

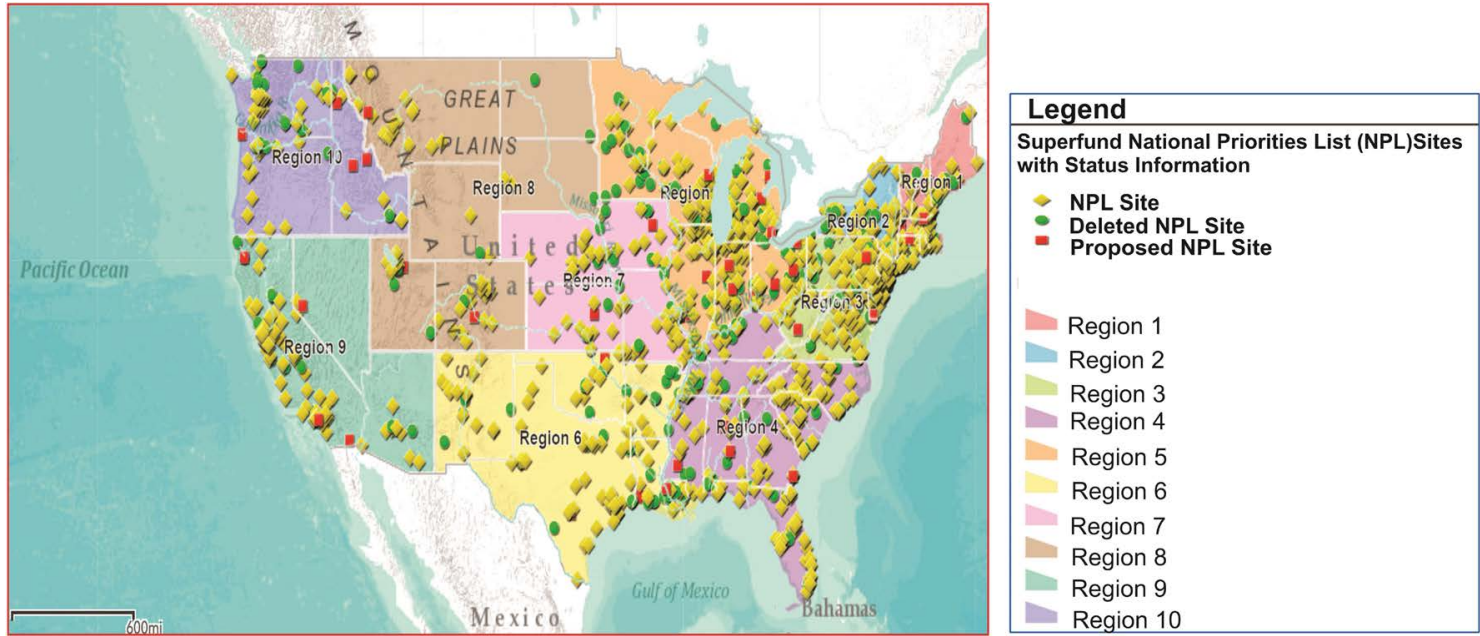

Figure 1. Superfund National Priorities List (NPL) sites with Status Information. [Image Courtesy of ESRI, NOAA, USGS and U.S. Environmental Protection Agency [4].

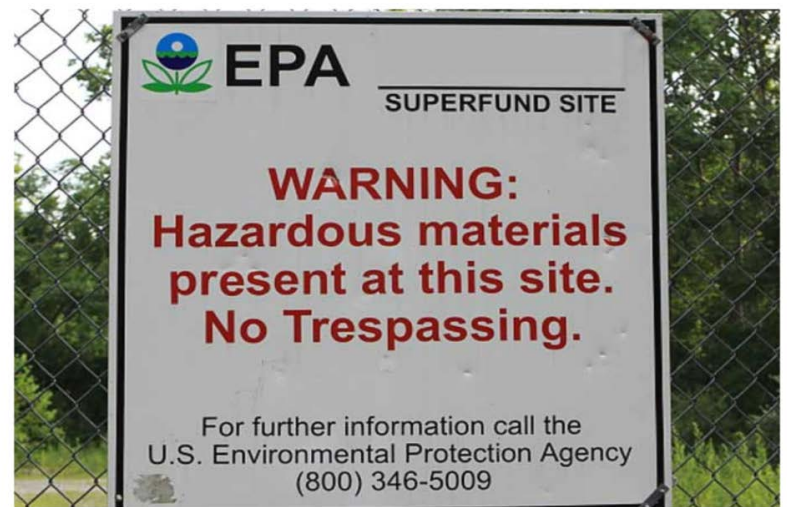

Figure 2. EPA Sign Board showing superfund site (Image courtesy of EPA).

analyzing chemical spills and Hazardous waste sites pollution. The study therefore uses GIS to spatially geocode the affected toxic site areas in Louisiana.

\section{Geocoding of Environmental Pollution Using Geographic Information System (GIS)}

GIS has emerged as an important tool for integrating geo-referenced data on pollution assessment. It is also a spatial system for the organization, storage, transformation, retrieval, and analysis of data where location is important [5]-[9]. The ability of GIS to visualize different land features and environmental dataset GIS techniques combined with other methods such as Geostatistics play an important role in geocoding of environmental pollution as well as visualization of data in a spatial environment [10] [11] [12] [13]. Numerous studies have used these tools to determine and map spatial distribution and behavior of pollutants in urban areas [14]-[24]. There are also many studies worldwide that have used GIS to locate and geocode toxic and other environmental waste pollutions [25]-[29]. Other studies such as Yesilonis et al. [30] combined GIS techniques with prin- 
cipal components analysis and univariate statistical procedures to spatially locate above-background contents of the contaminated heavy metals $\mathrm{Cd}, \mathrm{Co}, \mathrm{Cu}, \mathrm{Cr}$, $\mathrm{Fe}, \mathrm{Mn}, \mathrm{Ni}, \mathrm{Pb}, \mathrm{Ti}, \mathrm{V}$, and $\mathrm{Zn}$ in surface soils in Baltimore City. Similar work is done in urban setting, Nazarpour et al. [31] used GIS to spatially locate toxic metal contamination of the urban industrial city of Ahvaz in Southwest Iran. In Ho Chi Minh City, Vietnam, Quang et al. [32] determined the concentration and distribution of heavy metals in soil by using Geostatistics and GIS techniques. Results of their study highlighted spatial distribution and contamination of heavy metals in the city. The objectives of this study were two-fold-firstly, to use GIS techniques to spatially geocode the affected toxic site areas in Louisiana, and secondly, to use information obtained from geocoded maps to help policy-makers plan for removal of toxic material.

\section{Methodology}

\subsection{The Study Area}

The focus of this study was on the State of Louisiana (Figure 3). The state of

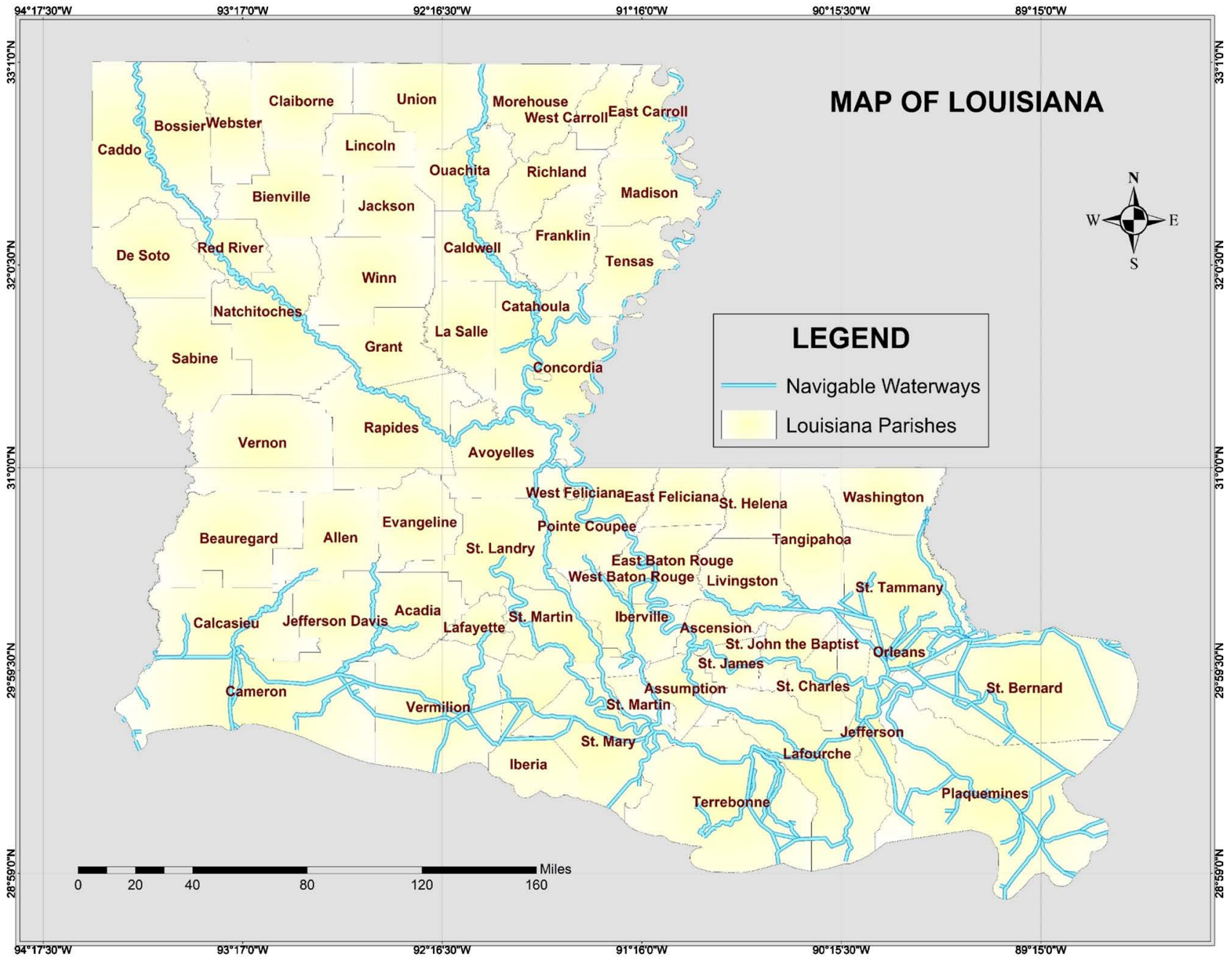

Figure 3. The state of Louisiana with the parishes. 
Louisiana is no stranger to the ramifications of man-made environmental disasters after the 2010 BP Deepwater Horizon oil spill painted 55 miles of the state's coastline black, with gallons of oil [33]. Almost a decade later the state continues to battle with issues of environmental contamination due to industrial toxins. This is no surprise considering Louisiana's thriving chemical industry which directly employs over 29,000 workers across its 64 parishes. This sector accounted for $\$ 80$ billion in sales in 2018 [34]. Although the chemical industry has been praised as the cornerstone of Louisiana's economy, it also greatly contributes to the downfall of environmental quality in the Bayou state. The number of sites in Louisiana on the EPA's National Priorities List (NPL) is 10, while 6 sites have been proposed to be added to the list. 13 sites, which had been previously remediated under the CERCLA act, were removed from the list [4] [35].

The list of contaminants identified across these sites was extensive, ranging from heavy metals such as lead, mercury, arsenic, and cadmium to explosives such as 2,4,6-trinitrotoluene (TNT) and dinitrotoluene (DNT), from a former Louisiana ammunitions plant. Several deposits of creosote, from old wood treatment facilities, were found in Slidell, Madisonville and Marion. Other contaminants identified included leachate from landfills, PCBs, and various organic and inorganic materials [36] [37]. There is no way of telling exactly when some of these pollutants were first introduced into the environment, but it is safe to assume that some of occurrences could be many decades old, considering the fact that some facilities had operations dating as far back as the early 1900s. The state of Louisiana, with its flourishing chemical industry, is littered with many polluted sites (Figure 4; Figure 5; Figure 6). There is also evidence of numerous instances of fracked gas blowout and flaring by petrochemical companies (Figure 5) [38]. Table 1 provides

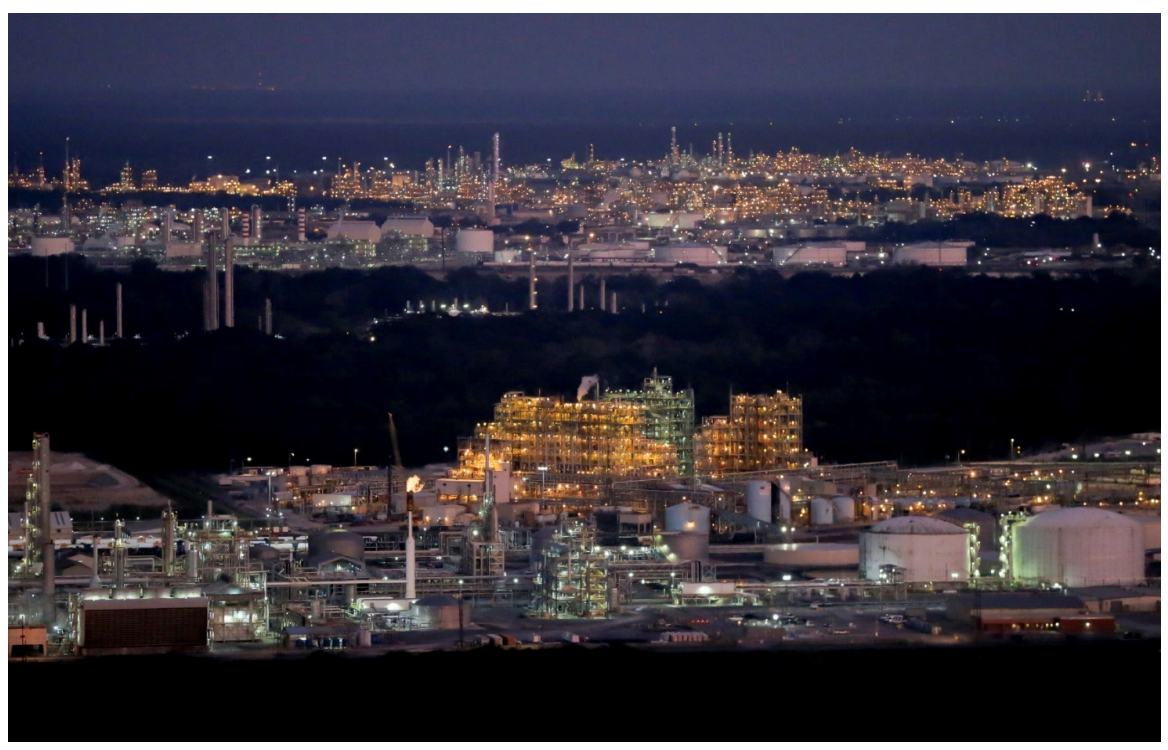

Figure 4. The Nutrien Gelsmar Nitrogen and Phosphate facility is seen in the foreground with several plants in the background. The bulk of Ascension Parish's heavy industry is around Gelsmar just downriver from St. Gabriel. Source: Image Courtesy of the Advocate Newspaper [36]. 


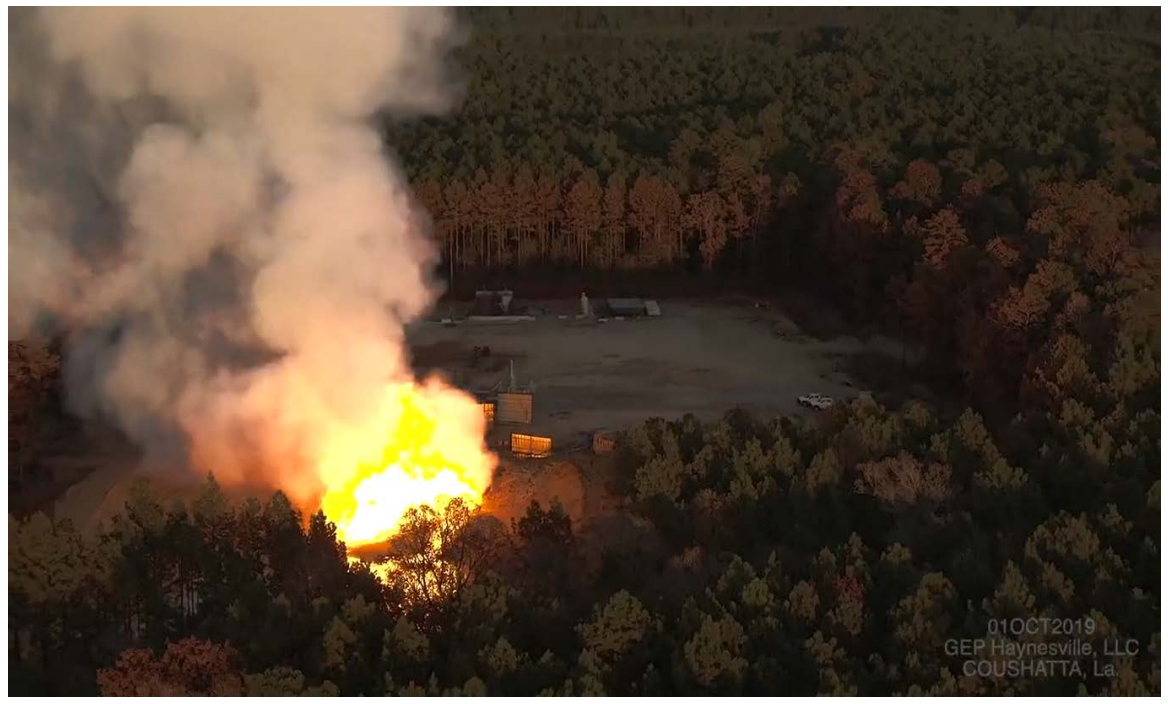

Figure 5. GEP Haynesville, LLC's blown out fracked gas wells in northwestern Louisiana. Source: Image Courtesy of the Advocate Newspaper [38].

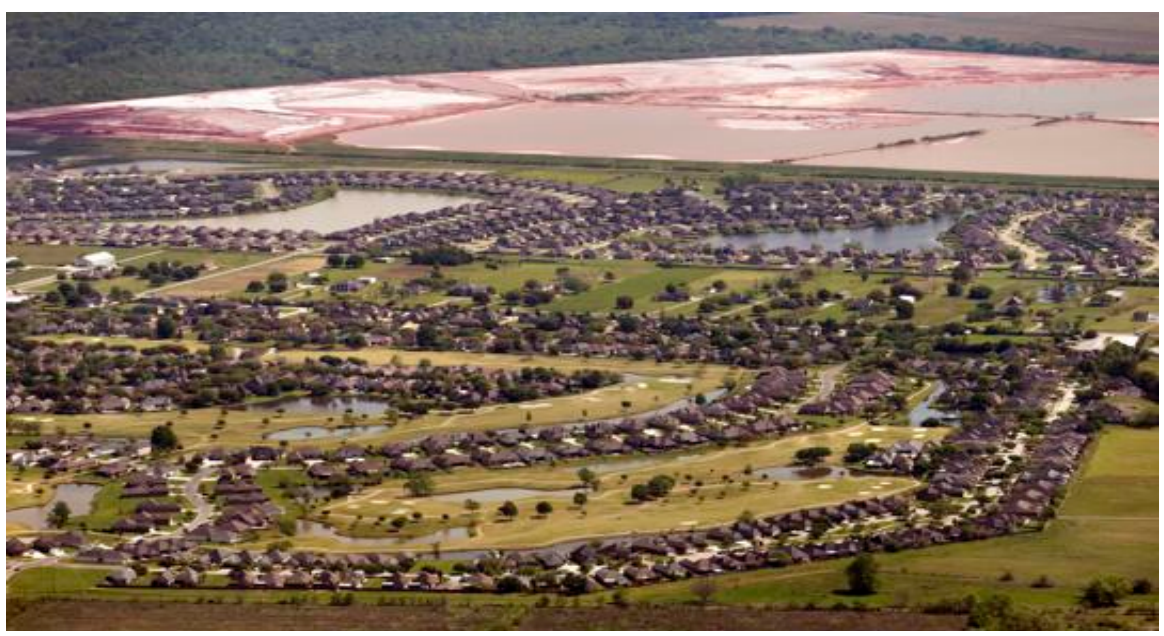

Figure 6. A chemical retaining pond is seen behind the new Pelican's Crossing neighborhood near the LAlumina LLC facility (previously Almatis Alumina) in Ascension Parish. Source: Image Courtesy of the Advocate Newspaper [39].

a summary of the active and proposed Superfund sites in Louisiana, the pollutant type at each location and a brief summary of the site's industrial history.

\subsection{Data Acquisition and Processing}

Data for this study was acquired from United States Environmental Protection Agency (EPA) website including names and locations of NPL and Super Fund sites in the state of Louisiana. Additional data was obtained from Ormsby et al. [40] and data from newspapers and journal publications [41] [42]. Also, publicly available EPA database that contains information on toxic chemical releases and other waste management activities reported annually by regulated industry groups and federal facilities was acquired [43]. Data obtained from EPA website was converted to geographic co-ordinates (latitude and longitude). To add the 
Table 1. Louisiana Superfund Sites, Active and Proposed. Toxic Sites on the NPL [4].

\begin{tabular}{|c|c|c|c|}
\hline NAME & LOCATION & CONTAMINANT & PREVIOUS INDUSTRIAL USAGE \\
\hline \multicolumn{4}{|l|}{ ACTIVE SUPERFUND SITES } \\
\hline Agricultural Street Landfill & New Orleans & Zinc, Mercury, Cadmium, Arsenic & Landfill (est. 1910) \\
\hline Bayou Bonfuca & Slidell & Creosote & Wood Treatment Facility (est. 1900) \\
\hline Madisonville Creosote Works & Madisonville & Creosote & Wood Treatment Facility (est. before 1950) \\
\hline Delta Shipyard & Houma & $\begin{array}{l}\text { Arsenic, antimony, lead, mercury, pyrene } \\
\text { and many other harzadous products }\end{array}$ & $\begin{array}{l}\text { Cleaning and repair facility for boats and } \\
\text { barges }\end{array}$ \\
\hline American Creosote & Winfield & $\begin{array}{l}\text { polychlorinated dibenzodioxins, } \\
\text { polychlorinated dibenzofurans, and various } \\
\text { carcinogenic and mutagenic polynuclear } \\
\text { aromatic hydrocarbons }\end{array}$ & Wood Treament Facility (est. 1910) \\
\hline Combustion Inc. & Denham Springs & $\begin{array}{l}\text { PCB's volatile organic chemicals, and heavy } \\
\text { metals (i.e. lead and thallium) }\end{array}$ & Handled non-reclaimable waste oil \\
\hline $\begin{array}{l}\text { Louisiana Army Ammunition } \\
\text { Plant }\end{array}$ & Doyline & $\begin{array}{l}\text { TNT, dinitrotoluene (DNT), phenols, } \\
\text { 4-DNT, tetryl, and cadmium }\end{array}$ & $\begin{array}{l}\text { Associated with loading, assembling, and } \\
\text { packing military ammunitions }\end{array}$ \\
\hline $\begin{array}{l}\text { EVR-Wood Treating/Evangeline } \\
\text { Refining Jennings Company }\end{array}$ & Jennings & Metals & Wood treatment facility and oil refinery \\
\hline Marion Pressure Treating & Marion & Creosote & Wood treatment facility (1964-1989) \\
\hline $\begin{array}{l}\text { Petro-Processors of Louisiana } \\
\text { Inc. }\end{array}$ & Scotlandville & Leachate & $\begin{array}{l}3 \text { - } 5 \text { million cubic feet pf contaminated } \\
\text { material potentially stored in on-site } \\
\text { enclosed pits }\end{array}$ \\
\hline \multicolumn{4}{|l|}{ PROPOSED SUPERFUND SITES } \\
\hline $\begin{array}{l}\text { Calcasieu Estuary (formerly } \\
\text { Bayou D’Inde) }\end{array}$ & Calcasieu & Various organic and inorganic materials & $\begin{array}{l}\text { Organic and inorganic materials were } \\
\text { disposed into the Calcasieu Estuary }\end{array}$ \\
\hline Colonial Creosote & Washington & Polycyclic aromatic hydrocarbons (PAHs) & Wood treatment facility \\
\hline Devil's Swamp Lake & Scotlandville & PCBs & $\begin{array}{l}\text { Waste management facility, hazardous waste } \\
\text { disposal facility and discharge point for } \\
\text { treated wastewater }\end{array}$ \\
\hline $\begin{array}{l}\text { Gulf States Utilities-North Ryan } \\
\text { Street }\end{array}$ & Lake Charles & PAHs, copper and lead & Landfill for utility operations \\
\hline Highway 71/72 Refinery & Bossier City & Lead and mercury & CITGO refinery site \\
\hline SBA Shipyard & Jefferson Davis & TBD & TBD \\
\hline
\end{tabular}

data obtained from EPA website into ArcMap, information was inputted into a Microsoft Excel spreadsheet and reformatted appropriately to be able to import it into ArcGIS. Then, shape files containing the states and the parish boundaries were added to the GIS project. Using a common attribute between the GIS shape file and the Microsoft Excel file, the Microsoft Excel data was joined with the attribute table of the shape files. Summary of data acquisition and processing and are shown in Figure 7.

\section{Results and Discussion}

Figure 8 shows geocoded EPA toxic sites in Louisiana. Figure 9 also displays 
some of the abandoned pits in Louisiana. Figure 10 and Figure 11 display an abandoned pit and remediation Plan Sites, and 2019 Louisiana toxic release inventory, respectively. The abandoned pits shown in Figure 9 pose risks to underground and surface water systems that might be polluted from rainwater and surface runoff, respectively. They also pose health risks to the community living close

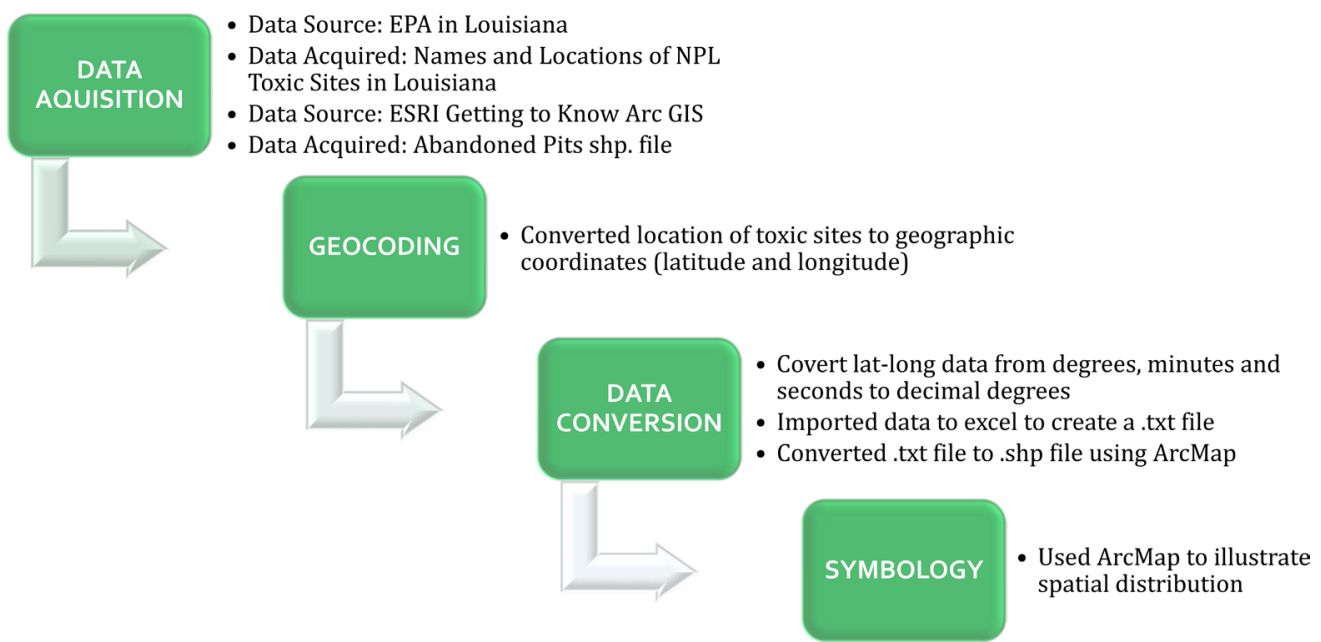

Figure 7. Data acquisition and processing flow chart.

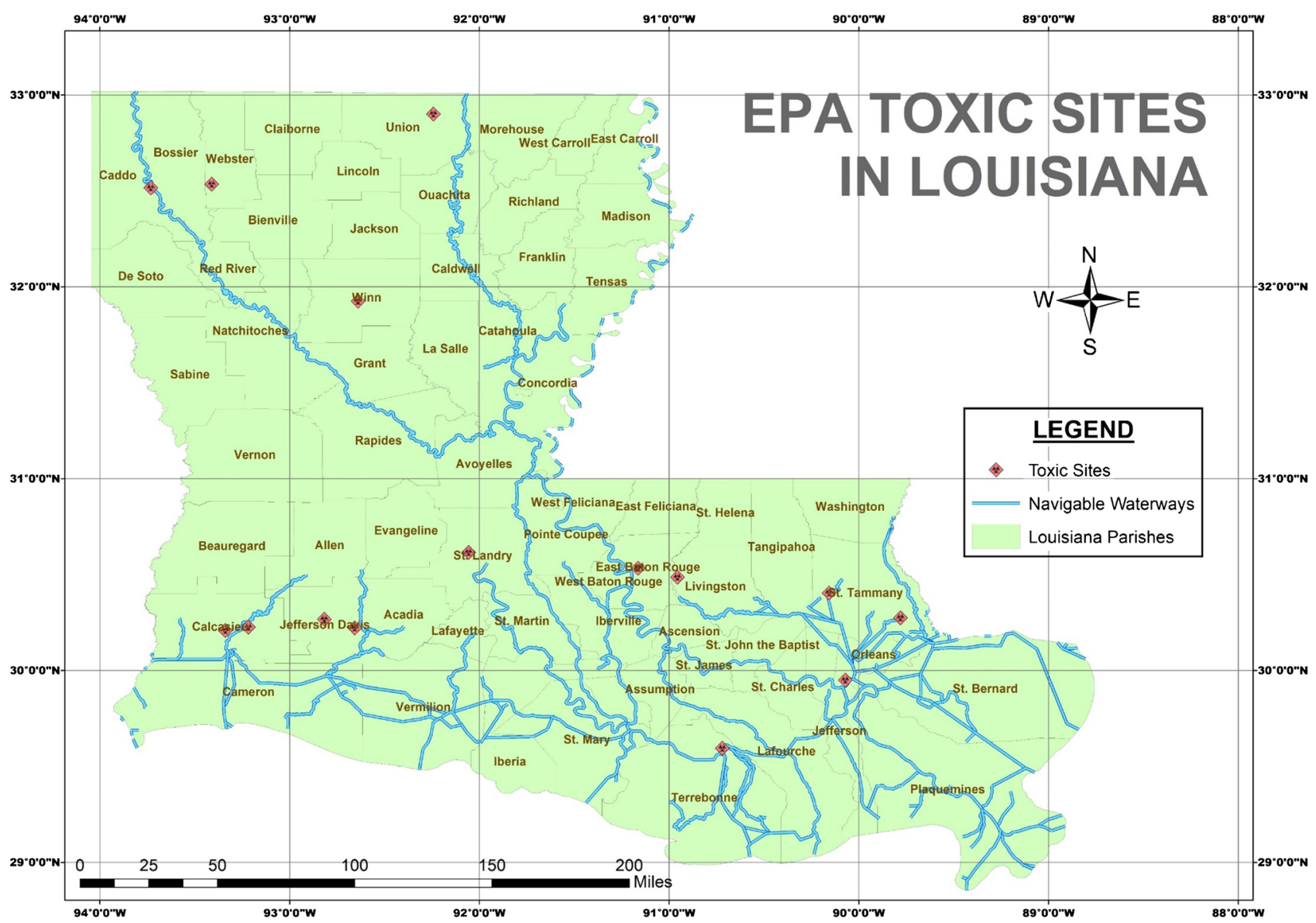

Figure 8. Geocoded EPA toxic sites in Louisiana. 


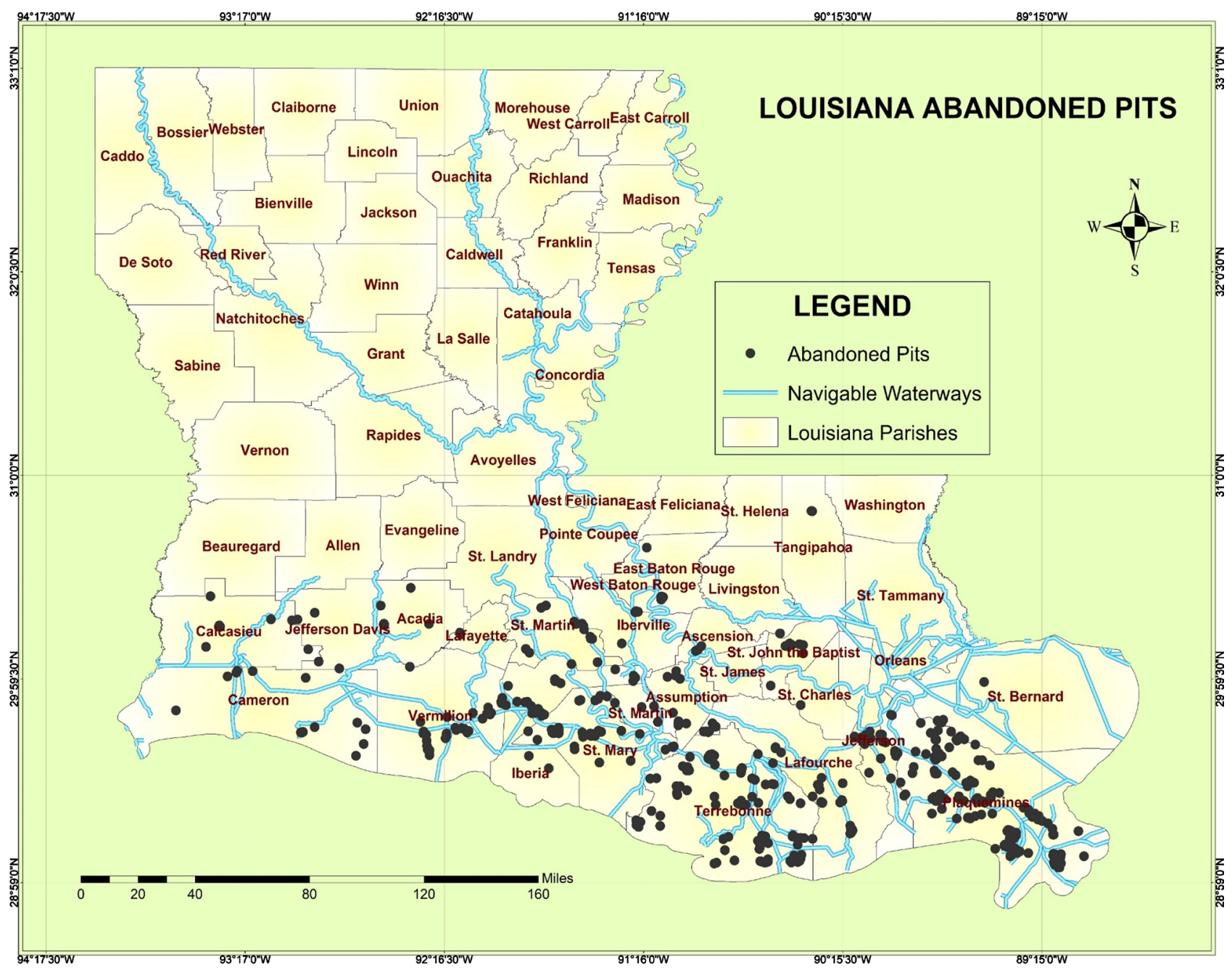

Figure 9. Abandoned pits in Louisiana.

to the facility through breathing air associated with toxic pollutants. Inhaling or breathing toxic air pollutants could increase chances of experiencing health problems [2] [3]. Across the state of Louisiana, $60 \%$ of NPL listed toxic sites are either in direct contact with or in close proximity to major waterways, and 75\% are distributed across the southern Louisiana region (Figure 9 and Figure 10). Studies have shown that race, ethnicity, and other socioeconomic factors such as property value and educational attainment, strongly affect the location of hazardous waste sites [44] [45].

Dozens of contaminated toxic sites are scattered across Louisiana. 10 sites are on the EPA's NPL 606 abandoned pits. Hazardous waste pollution has extensive ecological impacts. Leaching of toxic chemicals and byproducts can cause soil contamination, increasing community exposure risks and making land unfit for agricultural use. Contamination of ground and surface water supplies threatens availability of clean water for consumption and agricultural use. Additionally, contaminants can cause health declines in exposed flora and fauna, threatening ecosystem structure and function. Further impacts of toxic waste on ecosystems 


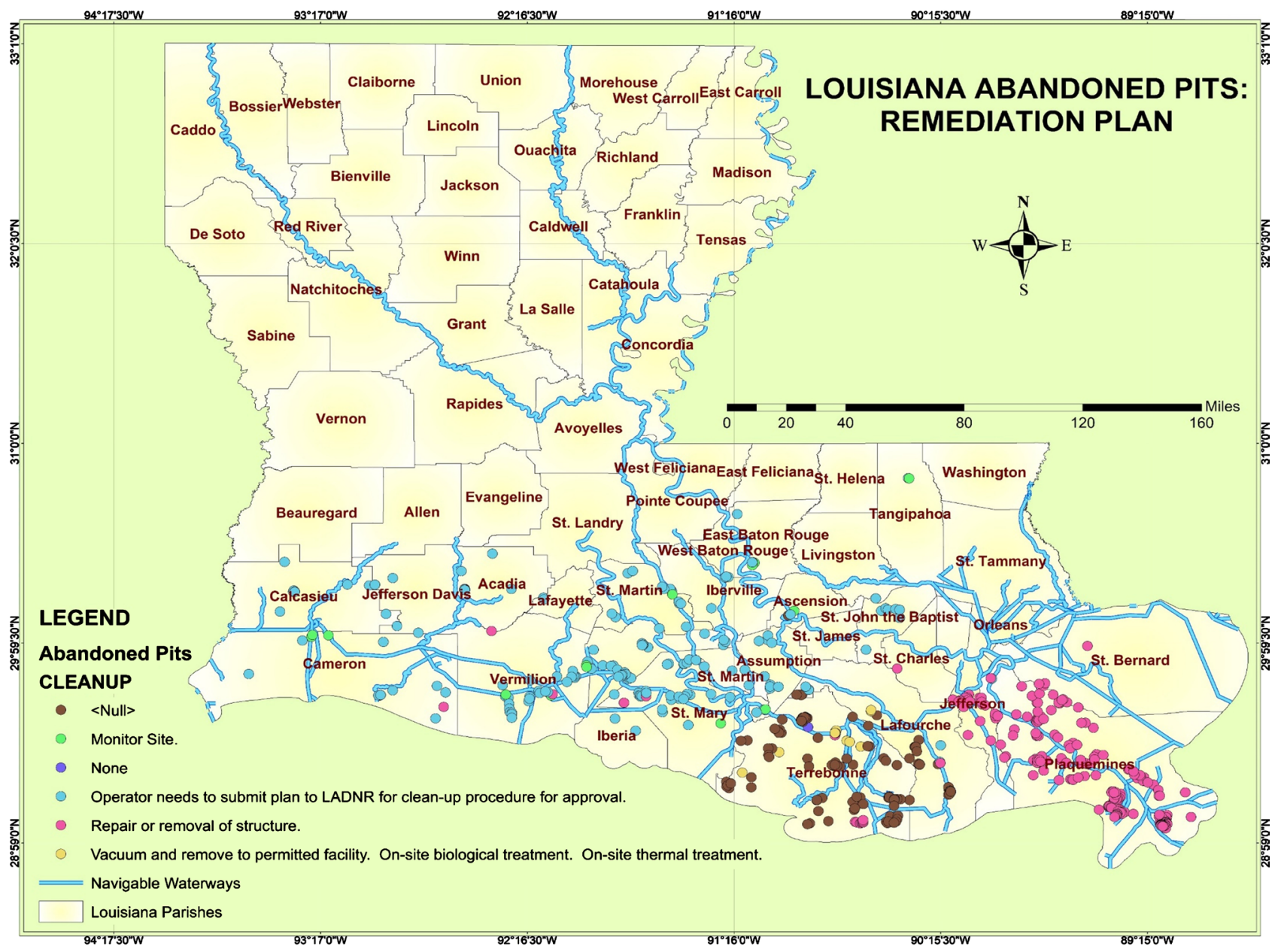

Figure 10. Abandoned pits and remediation plan sites in Louisiana.

is shown in Figure 13 [46]. Contaminants include heavy metals, carcinogens and lead. Hazardous waste contaminates the environment and water supplies. It also kills marine wildlife and creates uninhabitable environments. The abandoned pits remediation plan shown in Figure 12, gives details steps to be taken in order to clean the chemical wastes from the environment.

This study found that some activities, by petrochemical companies contributing significantly to pollution via fracked gas blowout and flaring (burning of chemicals in an open flame) were commonly practiced as shown in Figure 5 [37]. Gas flaring is one of the causes of emission. It also generates toxic compounds that harm human health and the ecosystem. Several studies have shown that not only is plant productivity affected, but also soil characteristics as well as contamination of surface drainage systems [26] [47].

\section{Policy Recommendations and Conclusion}

To tackle the issue of flaring with attendant emission problems, there is the need for strict enforcement of the State law that deals with fracking and flaring. Companies found guilty should be made to pay heavy fines and clean up or even 


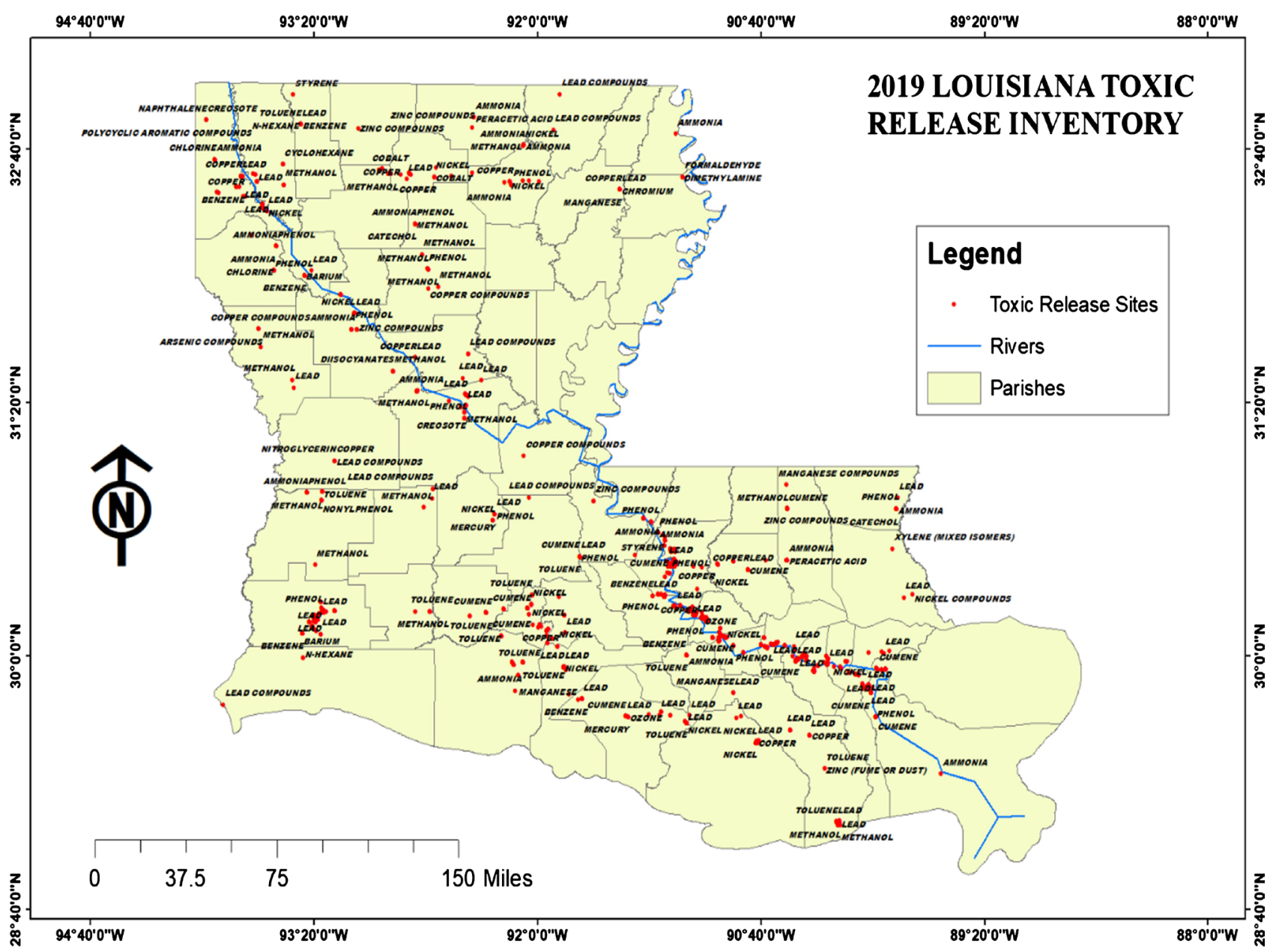

Figure 11. 2019 Louisiana toxic release inventory.

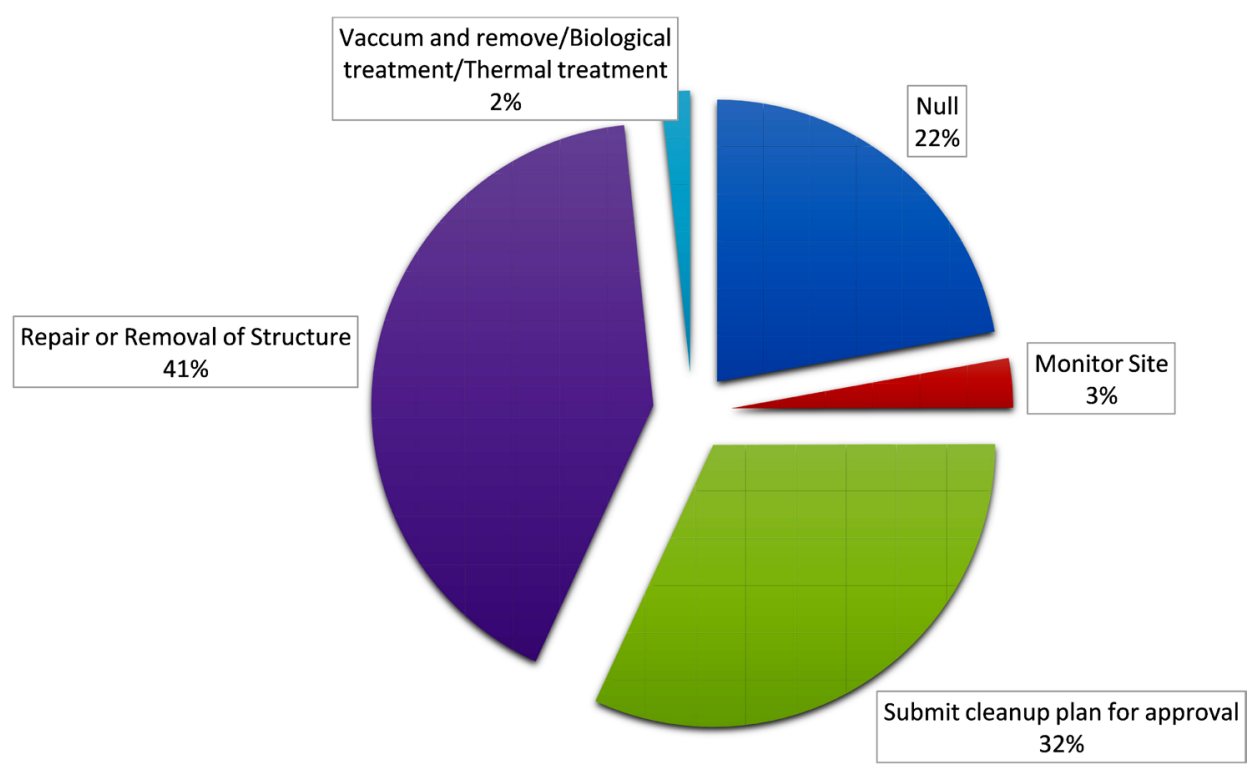

- Null Monitor Site $\quad$ Submit cleanup plan for approval @ Repair or Removal of Structure

- Vaccum and remove/Biological treatment/Thermal treatment

Figure 12. Abandoned pits remediation plan. 


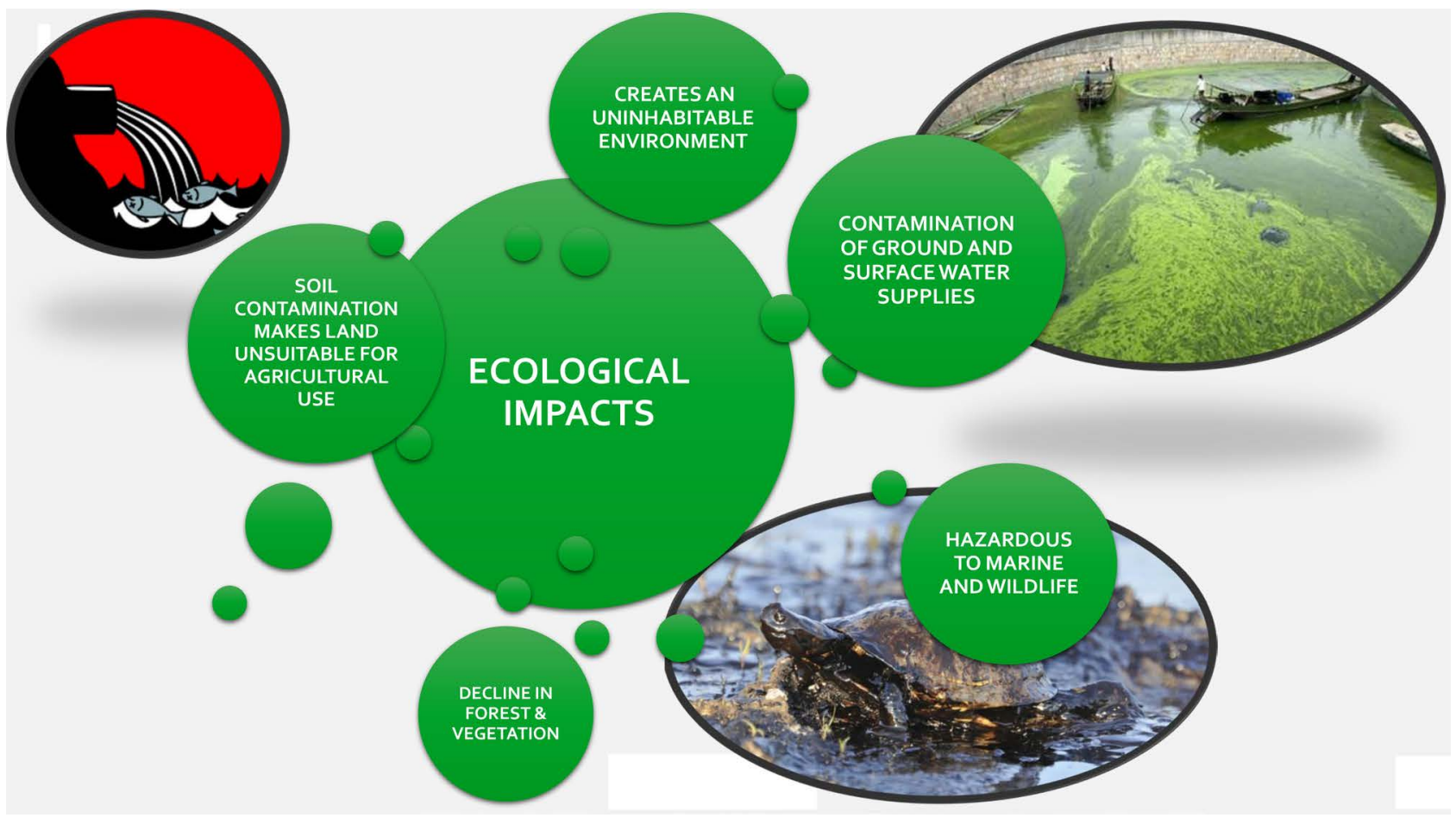

Figure 13. Some of the ecological impacts of toxic waste.

close their operations. Each year Louisiana Department of Environmental Quality and EPA publish emission inventories and air quality reports. Scientists should be made to use inventories of emissions as tools when developing atmospheric models. This would assist policy makers in developing cost-effective emission control strategies that are necessary for tracking the progress of policies towards gas emissions reduction. Recent announcement by Governor John Bel Edwards to address sea level rise by reducing greenhouse gas emissions from the oil and gas industry [48] is in the right direction, since, emissions play an important role in global warming. There is also the need to increase funding for the clean-up of the chemical waste. Report by Mitchell [49] noted with concerns about lack of funding to clean up the chemical waste. Most of the hazardous facilities could not be cleaned as fast as possible because of lack of funding. Accordingly, without remedial action, the extent of contamination would expand, and the impacts will continue to worsen.

\section{Conflicts of Interest}

The authors declare no conflicts of interest regarding the publication of this paper.

\section{References}

[1] Parameswaran, S. (2013) Toxic Waste "Major Global Threat". BBC Tamil Service, 20 November 2013. https://www.bbc.com/news/science-environment-24994209

[2] United States Environmental Protection Agency (EPA) (2016) Risk Assessment for Toxic Air Pollutants: A Citizen's Guide Originally Published as EPA 450/3-90-024; 
March 1991. https://www3.epa.gov/airtoxics/3_90_024.html

[3] Lemke, L., Lamerato, L., Xu, X., Booza, J.C., Reiners Jr., J.J., Raymond III, D.M., Villeneuve, P.J., Lavigne, E., Larkin, D. and Krouse, H.J. (2014) Geospatial Relationships of Air Pollution and Acute Asthma Events across the Detroit-Windsor International Border: Study Design and Preliminary Results. Journal of Exposure Science and Environmental Epidemiology, 24, 346-357.

https://doi.org/10.1038/jes.2013.78

[4] United States Environmental Protection Agency (EPA) (2017) Superfund National Priorities List (NPL) Where You Live Map.

https://www.epa.gov/superfund/search-superfund-sites-where-you-live

[5] Aronoff, S. (1989) Geographical Information Systems: A Management Perspective. WDL Publications, Ottawa.

[6] DeMers, M.N. (2008) Fundamentals of Geographic Information Systems. 4th Edition, Wiley, New York.

[7] Burrough, P.A., McDonnell, R.A. and Lloyd, C.D. (2015) Principles of Geographical Information Systems. 4th Edition, Oxford University Press, Oxford.

[8] Longley, P.A., Goodchild, M.F., Maguire, D.J. and Rhind, D.W. (2015) Geographic Information Science and Systems. 4th Edition, John Wiley and Sons, Hoboken.

[9] Chang, K. (2019) Introduction to Geographic Information Systems. 9th Edition, McGraw-Hill Science/Engineering/Math, New York.

[10] Henshaw, S.L., Curriero, F.C., Shields, T.M., Glass, G.E., Strickland, P.T. and Breysse, P.N. (2004) Geostatistics and GIS: Tools for Characterizing Environmental Contamination. Journal of Medical Systems, 28, 335-348. https://doi.org/10.1023/B:JOMS.0000032849.42310.4e

[11] Messier, K.P., Yasuyuki, A. and Serre, M.L. (2012) Integrating Address Geocoding, Land Use Regression, and Spatiotemporal Geostatistical Estimation for Groundwater Tetrachloroethylene. Environmental Science Technology, 46, 2772-2780. https://doi.org/10.1021/es203152a

[12] Johnson, C. (2015) Using Kriging, Cokriging, and GIS to Visualize Fe and Mn in Groundwater. Electronic Theses and Dissertations, Paper 2498. https://dc.etsu.edu/etd/2498

[13] Agyeman, A.B.A. (2017) Vulnerability Assessment of Groundwater to $\mathrm{NO}_{3}$ Contamination Using GIS, DRASTIC Model and Geostatistical Analysis. Electronic Theses and Dissertations, Paper 3264. https://dc.etsu.edu/etd/3264

[14] Gong, M., Wu, L., Bi, X.Y., Ren, L.M., Wang, L., Ma, Z.D., et al. (2010) Assessing Heavy-Metal Contamination and Sources by GIS-Based Approach and Multivariate Analysis of Urban-Rural Topsoils in Wuhan, Central China. Environmental, Geochemistry and Health, 32, 59-72. https://doi.org/10.1007/s10653-009-9265-2

[15] Guagliardi, I., Cicchella, D. and De Rosa, R. (2012) A Geostatistical Approach to Assess Concentration and Spatial Distribution of Heavy Metals in Urban Soils. Water, Air and Soil Pollution, 223, 5983-5998.

https://doi.org/10.1007/s11270-012-1333-Z

[16] M. Imperatoa, M., Adamob, P., Naimoa, D., Arienzob, M., Stanzionea, D. and Violanteb, P. (2003) Spatial Distribution of Heavy Metals in Urban Soils of Naples City (Italy). Environmental Pollution, 124, 247-256. https://doi.org/10.1016/S0269-7491(02)00478-5

[17] Lee, C.S., Li, X., Shi, W., Cheung, S.C. and Thornton, I. (2006) Metal Contamination in Urban, Suburban, and Country Park Soils of Hong Kong: A Study Based on 
GIS and Multivariate Statistics. Science of the Total Environment, 356, 45-61. https://doi.org/10.1016/j.scitotenv.2005.03.024

[18] Shi, J., Wang, H., Xu, J., Wu, J., Liu, X., Zhu, H., et al. (2007) Spatial Distribution of Heavy Metals in Soils: A Case Study of Changxing, China. Environmental Geology, 52, 1-10. https://doi.org/10.1007/s00254-006-0443-6

[19] Cicchella, D., De Vivo, B., Lima, A., Albanese, S. and Fedele, L. (2008) Urban Geochemical Mapping in the Campania Region (Italy). Geochemistry. Exploration, Environment, Analysis, 8, 19-29. https://doi.org/10.1144/1467-7873/07-147

[20] Morton-Bermea, O., Hernandez-Alvarez, E., Gonzalez-Hernandez, G., Romero, F., Lozano, R. and Beramendi-Orosco, L.E. (2009) Assessment of Heavy Metal Pollution in Urban Topsoils from the Metropolitan Area of Mexico City. Journal of Geochemical Exploration, 101, 218-224.

https://doi.org/10.1016/j.gexplo.2008.07.002

[21] Nas, B. (2009) Geostatistical Approach to Assessment of Spatial Distribution of Groundwater Quality. Polish Journal of Environmental Studies, 18, 1073-1082.

[22] Sollito, D., Romic, M., Castrignano, S., Romic, D. and Bakic, H. (2010) Assessing Heavy Metal Contamination in Soils of the Zagreb Region (Northwest Croatia) Using Multivariate Geostatistics. Catena, 80, 182-194.

https://doi.org/10.1016/j.catena.2009.11.005

[23] Rodriguez-Salazar, M.T., Morton-Bermea, O., Hernandez-Alvarez, E., Lozano, R. and Tapia-Cruz, V. (2011) The Study of Metal Contamination in Urban Topsoils of Mexico City Using GIS. Environmental Earth Sciences, 62, 899-905. https://doi.org/10.1007/s12665-010-0584-5

[24] Yuan, G.L., Sun, T.H., Han, P. and Li, J. (2013) Environmental Geochemical Mapping and Multivariate Geostatistical Analysis of Heavy Metals in Topsoils of a Closed Steel Smelter: Capital Iron \& Steel Factory, Beijing, China. Journal of Geochemical Exploration, 130, 15-21. https://doi.org/10.1016/j.gexplo.2013.02.010

[25] Young, E.A. (2006) Monitoring and Measuring the Impacts and Environmental Implications of Flood Events on Contaminated Sediment Dispersal in the River Swale Catchment, North Yorkshire. University of Central Lancashire, Doctoral Thesis, University of Central Lancashire. http://clok.uclan.ac.uk/20036

[26] Merem, E.C., Twumasi, Y.A., Yerramilli, S. and Richardson, C. (2012) The Use of Geospatial Information Systems in the Analysis of Pollution Trends in Southern Mississippi Region. American Journal of Science and Engineering, 1, 1-16.

[27] Maryam, Z. (2015) Spatial Distribution of Sediment Pollution in the Khajeh Kory River Using Kriging and GIS. Earth Sciences Research Journal, 18, 173. https://doi.org/10.15446/esrj.v18n2.44491

[28] Alibrahim, Z.O., Williams, C.D. and Roberts, C.L. (2017) A GIS-Based Spatial Distribution and Evaluation of Selected of Selected Heavy Metals Contamination in Top Soil around Ectone Mining Area, Derbyshire, UK. International Journal of Geological and Environmental Engineering, 11, 380-391.

[29] Mihailović, A., Budinski-Petković, L.J., Popov, S., Ninkov, J., Vasinb, J., Ralević, N.M. and Vučinić Vasić, M. (2015) Spatial Distribution of Metals in Urban Soil of Novi Sad, Serbia: GIS Based Approach. Journal of Geochemical Exploration, 150, 104-114. https://doi.org/10.1016/j.gexplo.2014.12.017

[30] Yesilonis, I.D., Pouyat, R.V. and Neerchal, N.K. (2008) Spatial Distribution of Metals in Soils in Baltimore, Maryland: Role of Native Parent Material, Proximity to Major Roads, Housing Age and Screening Guidelines. Environmental Pollution, 156, 723-731. https://doi.org/10.1016/j.envpol.2008.06.010 
[31] Nazarpour, A., Watts, M.J., Madhani, A. and Elahi, S. (2019) Source, Spatial Distribution and Pollution Assessment of $\mathrm{Pb}, \mathrm{Zn}, \mathrm{Cu}$, and $\mathrm{Pb}$, Isotopes in Urban Soils of Ahvaz City, a Semi-Arid Metropolis in Southwest Iran. Scientific Reports, 9, 5349. https://doi.org/10.1038/s41598-019-41787-w

[32] Quang, T.T., Chou, T.Y., Van, H.T., Chen, H.M., Mon, D. and Tung, L.H. (2018) GIS-Based Techniques for Estimating Spatial Distribution of Heavy Metals in Urban Soil: A Case Study in Hoc Mon District, Ho Chi Minh City, Vietnam. International Refereed Journal of Engineering and Science, 7, 25-29.

[33] Ducumentary, M. (2017) Top 10 Worst Man Made Environmental Disasters. https://www.youtube.com/watch?v=PcLrH2eIOWI

[34] Karlin, S. (2018) Chemical Sector Supports Nearly \$80 Billion in Sales Industry Sales Study.

https://www.theadvocate.com/baton_rouge/news/business/article_e348431c-5396-1 1e8-aa28-f3bbd1d6f2a0.html

[35] United States Environmental Protection Agency (EPA) in Louisiana (2018) Cleanups in Louisiana. https://www.epa.gov/la/cleanups-louisiana

[36] Baurick, T., Younes, L. and Meiners, J. (2019) Industrial Corridor Is Already Polluted, and More Plants Are on the Way. The Advocate, Baton Rouge, LA (October 31, 2019), 95th Year, No. 123, 1A, 4A-9A.

[37] Schleifstein, M. (2019) A Reporter Who Has Investigated Industrial Pollution for 35 Years Sees Progress Reversed. The Advocate, Baton Rouge, LA (October 31, 2019), 95th Year, No. 123, 1A, 4A-9A.

[38] Dermansky, J. (2019) Already Burning for a Month, Fracked Gas Blowout in Louisiana Could Last Two More Months. DESMOG.

https://www.desmogblog.com/2019/10/04/burning-fracked-gas-blowout-louisianahealth-impacts

[39] Meiners, J. (2019) Wealthy Areas Are Not Immune to La. Toxic Pollution. The Advocate, Baton Rouge, LA (November 1, 2019), 95th Year, No. 124, $1 \mathrm{~A}$ and 6A.

[40] Ormsby, T., Napoleon, E., Groessl, R.B.C. and Bowden, L. (2010) Getting to Know ArcGIS Desktop: For ArcGIS 10. ESRI Press, Redland.

[41] Louisiana Environment Action Network (2019) The Louisiana Citizens Guide to Environmental Engagement.

https://leanweb.org/tools-resources/louisiana-citizens-guide-environmental-engage ment/chapter-5-land/5-1-superfund

[42] Louisiana Environment and Flood Control (2017) Toxic Sites in Louisiana: 15 of the States Most Polluted Places.

https://www.nola.com/news/environment/article_96f6f003-a44a-56da-bc3d-6546c6 e1969d.html

[43] United States Environmental Protection Agency (EPA) (2019) The Toxics Release Inventory (TRI) EZ Search Retrieves Data from the TRI Database in Envirofacts. https://www.epa.gov/enviro/tri-ez-search

[44] Bullard, R.D. (2000) Dumping in Dixie: Race, Class, and Environmental Quality. Third Edition, Routledge, Abingdon-on-Thames.

[45] Denq, F., Constance, D.H. and Joung, S.S., (2000) The Role of Class, Status, and Power in the Distribution of Toxic Superfund Sites in Texas and Louisiana. Journal of Poverty, 4, 1-91. https://doi.org/10.1300/J134v04n04_05

[46] United States Environmental Protection Agency (EPA) (2017) Health and Ecological Hazards Caused by Hazardous Substances. 
https://www.epa.gov/emergency-response/health-and-ecological-hazards-caused-ha zardous-substances

[47] Merem, E.C. and Twumasi, Y.A. (2007) GIS Applications in Global Environmental Protection: The Case of Environmental Monitoring of Fossil Fuel Emission from Oil and Gas Activities in Africa. World Resource Review, 19, 657-680.

[48] Schleifstein, M. (2020) Gov. Edwards' Plan to Combat Sea Level Rise in Louisiana? It Starts with Greenhouse Gas Emissions. (NOLA February 20, 2020).

https://www.nola.com/news/environment/article_1d634622-5413-11ea-b273-bfe67a aa5fac.html

[49] Mitchell, D.J. (2019) Audit: Many Waste Sites Lack Funding Plan. The Advocate, Baton Rouge, LA (November 15, 2019), 1B and 2B. 